\title{
Phenotypic and genetic heterogeneity of lactic acid bacteria isolated from "Alheira", a traditional fermented sausage produced in Portugal
}

\author{
Helena Albano ${ }^{a}$, Carol A. van Reenen ${ }^{\text {b }}$, Svetoslav D. Todorov ${ }^{\text {b }}$, Diana Cruz ${ }^{a}$, Luisa Fraga ${ }^{a}$, Tim Hogg ${ }^{a}$, \\ Leon M.T. Dicks ${ }^{\mathrm{b}}$, Paula Teixeira ${ }^{\mathrm{a}, *}$ \\ ${ }^{a}$ CBQF, Escola Superior de Biotecnologia, Universidade Católica Portuguesa; Rua Dr. António Bernardino de Almeida, 4200-072 Porto, Portugal \\ ${ }^{\mathrm{b}}$ Department of Microbiology, Stellenbosch University, Stellenbosch, Private Bag X1, Matieland 7602, South Africa
}

Keywords:

Lactic acid bacteria

Naturally fermented sausages

PCR

RAPD

\begin{abstract}
A B S T R A C T
The aim of this study was to evaluate the phenotypic and genetic heterogeneity of lactic acid bacteria (LAB) isolated from "Alheira", a fermented sausage produced in Portugal.

LAB were identified to genus and species level by phenotypic characteristics, using genus or speciesspecific primers and sequencing of the gene encoding 16S rRNA. Two-hundred and eighty-three isolates were grouped into 14 species. Lactobacillus plantarum was isolated from all sausages and Enterococcus faecalis from most of the samples. Low numbers of Lactobacillus paraplantarum, Lactobacillus brevis, Lactobacillus rhamnosus, Lactobacillus sakei, Lactobacillus zeae, Lactobacillus paracasei, Leuconostoc mesenteroides, Pediococcus pentosaceus, Pediococcus acidilactici, Weissella cibaria, Weissella viridescens and Enterococcus faecium were recorded. The genetic heterogeneity of $L$. plantarum and $E$. faecalis strains were determined by numerical analysis of DNA banding patterns obtained by RAPD-PCR. Strains of L. plantarum and E. faecalis were different from different producers. This study forms the basis from which starter cultures could be selected for production of "Alheira".
\end{abstract}

\section{Introduction}

"Alheira" is a fermented sausage typical of the Northern regions in Portugal (Trás-os-Montes). The product is produced by boiling meat (pork and/or poultry) in lightly salted and spiced water. Slices of bread are then added to a level of approximately $25 \%$ of the total raw material. Fine cut portions of meat, spices and olive oil or fat is then added. The paste is stuffed into cellulose-based casings and allowed to ferment naturally (i.e. without the addition of starter cultures), during a smoking process. Additional salt and spices are added according to taste, the sausages are bent into a horseshoe shape (approximately $15 \mathrm{~cm}$ long and $6 \mathrm{~cm}$ in diameter) and smoked for a maximum of eight days at temperatures below $37^{\circ} \mathrm{C}$ at uncontrolled humidity. The shelf life of "Alheiras" is about 1 month stored at $4{ }^{\circ} \mathrm{C}$ in air or longer if the sausages are packed under modified atmosphere. "Alheiras" are cooked before consumption; either by frying, grilling or boiling. The taste is described as being pleasant, lightly smoked, very particular, with a hint of garlic. The lightly smoked aroma is described as sui generis.

Although the aroma and flavour characteristics of "Alheira" and other fermented meat sausages are mainly influenced by the quality and origin of the raw materials and the ripening process, the composition of the microflora, especially lactic acid bacteria (LAB), plays a key role (Moretti et al., 2004; Papamanoli, Kotzekidou, Tzanetakis, \& Litopoulou-Tzanetaki, 2003). Lactobacillus sakei, Lactobacillus curvatus and Lactobacillus plantarum are the dominant species in fermented meat sausages, but seldom reach numbers in excess of $10^{7} \mathrm{cfu} / \mathrm{g}$ (Talon, Leroy, \& Lebert, 2007). Apart from the production of lactic acid and antimicrobial compounds such as bacteriocins (Bacus, 1986), LAB produce a number of other antimicrobial and organoleptic compounds, e.g. acetic acid, ethanol, acetoin, carbon dioxide and pyruvic acid (Bacus, 1986).

In general, sausages that undergo a short fermentation, without starter cultures, have a higher $\mathrm{pH}$ and thus also a larger population of Enterococcus spp. (Dellapina, Blanco, Pancini, Barbuti, \& Campanini, 1994). The proportion of enterococci versus other LAB in fermented dry sausages is thus important. However, only a few papers have been published on the microbial composition of "Alheira" (Ferreira, Barbosa, Vendeiro et al., 2006; Ferreira, Barbosa, Silva et al., 2007) and even less is known about the role of enterococci in "Alheira".

The use of selected starter cultures is important to produce the desired flavour and aroma compounds and extend the shelf life of the product (Bacus, 1986). In most studies, LAB in fermented sausages have been identified based on simple physiological, biochemical and chemotaxonomic methods (Montel, Talon, 
Table 1

Species- and genus-specific primers used in PCR reactions $\left({ }^{*}=\right.$ genus-pecific primers $)$.

\begin{tabular}{|c|c|c|c|c|c|c|}
\hline Species & Primer pair/sequence $\left(5^{\prime}-3^{\prime}\right)$ & $20 \mu \mathrm{l}$ reaction ${ }^{\mathrm{a}}$ & PCR-cycle & Origin (product size) & $\begin{array}{l}\text { Reference strain used as } \\
\text { positive control }\end{array}$ & Reference \\
\hline L. plantarum & $\begin{array}{l}\text { planF (F) CCG TTT ATG CGG AAC } \\
\text { ACC TA } \\
\text { REV (R) TCG GGA TTA CCA AAC ATC } \\
\text { AC }\end{array}$ & $\begin{array}{l}5.0 \mu \mathrm{l} \text { DNA, } 0.25 \mu \mathrm{l} \text { PlanF, } 0.5 \mu \mathrm{l} \text { REV, } 2.0 \mu \mathrm{l} \text { buffer } \\
10 \mathrm{x}, 1.6 \mu \mathrm{l} \text { dNTṔs, } 0.1 \mu \mathrm{l} \text { Taq }\end{array}$ & $\begin{array}{l}94^{\circ} \mathrm{C} / \\
30 \mathrm{~s} \\
56^{\circ} \mathrm{C} / 10 \mathrm{~s} \\
72{ }^{\circ} \mathrm{C} / 30 \mathrm{~s} \\
30 \text { cycles }\end{array}$ & $\begin{array}{l}\text { recA gene } \\
\text { (318 bp) }\end{array}$ & Lb. plantarum ATCC $14917^{\mathrm{T}}$ & $\begin{array}{l}\text { Torriani, Felis, and } \\
\text { Dellaglio (2001) }\end{array}$ \\
\hline L. paraplantarum & $\begin{array}{l}\text { ParaF (F) GTC ACA GGC ATT ACG } \\
\text { AAA AC } \\
\text { REV (R) TCG GGA TTA CCA AAC ATC } \\
\text { AC }\end{array}$ & $\begin{array}{l}5.0 \mu \mathrm{l} \text { DNA, } 0.5 \mu \mathrm{l} \text { ParaF, } 0.5 \mu \mathrm{l} \text { REV, } 2.0 \mu \mathrm{l} \text { buffer } 10 \mathrm{x} \text {, } \\
1.6 \mu \mathrm{l} \text { dNTṔs, } 0.1 \mu \mathrm{l} \mathrm{Taq}\end{array}$ & $\begin{array}{l}\text { b } 94{ }^{\circ} \mathrm{C} / \\
30 \mathrm{~s} \\
56^{\circ} \mathrm{C} / 10 \mathrm{~s} \\
72^{\circ} \mathrm{C} / 30 \mathrm{~s} \\
30 \text { cycles }\end{array}$ & $\begin{array}{l}\text { recA gene } \\
(107 \mathrm{bp})\end{array}$ & $\begin{array}{l}\text { Lb. paraplantarum ATCC } \\
700211^{\mathrm{T}}\end{array}$ & Torriani et al. (2001) \\
\hline L. rhamnosus & $\begin{array}{l}\text { Rham (R) TGC ATC TTG ATT TAA TTT } \\
\text { TG }\end{array}$ & $\begin{array}{l}5.0 \mu \mathrm{l} \text { DNA, } 2 \mu \mathrm{l} \text { Y2, } 2 \mu \mathrm{l} \text { Rham, } 2.0 \mu \mathrm{l} \text { buffer } 10 \mathrm{x}, \\
1.6 \mu \mathrm{l} \text { dNTṔs, } 0.1 \mu \mathrm{l} \mathrm{Taq}\end{array}$ & $\begin{array}{l}{ }^{\mathrm{b}} 94^{\circ} \mathrm{C} / \\
45 \mathrm{~s} \\
48^{\circ} \mathrm{C} / 45 \mathrm{~s} \\
72^{\circ} \mathrm{Cl} \\
1 \mathrm{~min} \\
30 \text { cycles }\end{array}$ & $\begin{array}{l}\text { 16S rRNA gene: } \mathrm{V} 1 \text { region } \\
\text { (290 bp) }\end{array}$ & Lb. rhamnosus ATCC $7469^{\mathrm{T}}$ & Ward and Timmins (1999) \\
\hline L. sakei & $\begin{array}{l}\text { Ls (R) ATG AAA CTA TTA AAT TGG } \\
\text { TAC }\end{array}$ & $\begin{array}{l}5.0 \mu \mathrm{l} \text { DNA, } 0.6 \mu \mathrm{l} 16,0.6 \mu \mathrm{l} \mathrm{Ls}, 2 \mu \mathrm{l} \mathrm{MgCl}, 2.0 \mu \mathrm{l} \\
\text { buffer } 10 \mathrm{x}, 2 \mu \mathrm{l} \text { dNTṔs, } 0.1 \mu \mathrm{l} \mathrm{Taq}\end{array}$ & $\begin{array}{l}{ }^{\mathrm{c}} 94^{\circ} \mathrm{C} / \\
1 \mathrm{~min} \\
47^{\circ} \mathrm{C} / 30 \mathrm{~s} \\
72^{\circ} \mathrm{C} / \\
1 \mathrm{~min} \\
35 \text { cycles }\end{array}$ & 16S rRNA gene (222 bp) & Lb. sakei DSMZ 20117 & $\begin{array}{l}\text { Berthier and Ehrlich } \\
\text { (1998) }\end{array}$ \\
\hline L. zeae & LBL R1 (R) CCA TGC ACC ACC TGT C & $\begin{array}{l}5.0 \mu \mathrm{l} \text { DNA, } 2 \mu \mathrm{l} \text { LCZ, } 2 \mu \mathrm{l} \text { LBLR1, } 2.0 \mu \mathrm{l} \text { buffer 10x, } \\
1.6 \mu \mathrm{l} \text { dNTṔs, } 0.1 \mu \mathrm{l} \text { Taq }\end{array}$ & $\begin{array}{l}{ }^{\mathrm{c}} 94^{\circ} \mathrm{C} / \\
30 \mathrm{~s} \\
40^{\circ} \mathrm{C} / 30 \mathrm{~s} \\
72^{\circ} \mathrm{Cl} \\
1 \mathrm{~min} \\
35 \text { cycles }\end{array}$ & 16S rRNA gene (985 bp) & & $\begin{array}{l}\text { Roy, Sirois, and Vincent } \\
\text { (2001) }\end{array}$ \\
\hline L. brevis & Br1 (F) CTT GCA CTG ATT TTA ACA & $\begin{array}{l}5.0 \mu \mathrm{l} \text { DNA, } 0.4 \mu \mathrm{l} \mathrm{Br} 1,0.4 \mu \mathrm{l} \mathrm{Br} 2,2.0 \mu \mathrm{l} \text { buffer 10x, } \\
1.6 \mu \mathrm{l} \text { dNTṔs, } 0.1 \mu \mathrm{l} \mathrm{Taq}\end{array}$ & $\begin{array}{l}{ }^{\mathrm{c}} 94^{\circ} \mathrm{C} / \\
1 \mathrm{~min} \\
52^{\circ} \mathrm{C} / 30 \mathrm{~s} \\
72^{\circ} \mathrm{Cl} \\
1 \mathrm{~min} \\
25 \text { cycles }\end{array}$ & 16S rRNA gene (1340 bp) & Lb. brevis ATCC 8287 & $\begin{array}{l}\text { Guarneri, Rossetti, and } \\
\text { Giraffa (2001) }\end{array}$ \\
\hline Ln. mesenteroides & $\begin{array}{l}\text { Lmes-f (F) AAC TTA GTG TCG CAT } \\
\text { GAC }\end{array}$ & $\begin{array}{l}5.0 \mu \mathrm{l} \text { DNA, } 1 \mu \mathrm{l} \text { Lmes-f, } 1 \mu \mathrm{l} \text { Lmes-r, } 4 \mu \mathrm{l} \mathrm{MgCl}, 2.0 \mu \mathrm{l} \\
\text { buffer 10x, } 4 \mu \mathrm{l} \text { dNTṔs, } 0.1 \mu \mathrm{l} \text { Taq }\end{array}$ & $\begin{array}{l}\text { d } 94^{\circ} \mathrm{Cl} \\
1 \mathrm{~min} \\
57^{\circ} \mathrm{Cl} \\
1 \mathrm{~min} \\
72^{\circ} \mathrm{Cl} \\
2 \mathrm{~min} \\
30 \text { cycles }\end{array}$ & $\begin{array}{l}\text { 16S rRNA gene } \\
(1150 \mathrm{bp})\end{array}$ & $\begin{array}{l}\text { Lb. mesenteroides subsp. } \\
\text { mesenteroides } \mathrm{NCDO} 523^{\mathrm{T}}\end{array}$ & Lee, Park, and Kim (2000) \\
\hline
\end{tabular}

TAC AA (R) AGT CGA GTT ACA GAC

30 cycles 
EntR (R)

AACTTCGTCACCAACGCGAAC

E. faecalis

\section{Ef0027F (R)}

GTCGTCCCTTTGGCAAAT

E. faecium

Enf1 (F)

ATTACGGAGACTACAATTTC

Ent2 (R)

TAGCGATAGAAGTTACATCAAC

$\operatorname{PacF}(\mathrm{F})$

PCAACTTCCGTTAATTCATTAT

PuR (R) ACCTTGCGGTCGTACTCC

PpeF (F) CGA ACT TCC GTT AAT TCA

TCA G

PUR (R) ACC TTG CGG TCG TAC TCC WeiF (F) CGT GGG AAA CCT ACC TCT TA

$5.0 \mu \mathrm{l}$ DNA, $2 \mu \mathrm{l}$ WeiF, $2 \mu \mathrm{l}$ WeiR, $0.1 \mu \mathrm{l} \mathrm{MgCl}, 2.0 \mu \mathrm{l}$

$5.0 \mu \mathrm{l}$ DNA, $2 \mu \mathrm{l}$ PacF, $2 \mu \mathrm{l}$ PuR, $4 \mu \mathrm{l} \mathrm{MgCl}, 2.0 \mu$ buffer 10x, $1.6 \mu$ dNTṔs, $0.1 \mu \mathrm{l} \mathrm{Taq}$

$5.0 \mu \mathrm{l} \mathrm{DNA}, 2 \mu \mathrm{l}$ PpeF, $2 \mu \mathrm{l}$ PuR, $4 \mu \mathrm{l} \mathrm{MgCl}$, $2.0 \mu$ uffer 10x, $1.6 \mu \mathrm{l}$ dNTṔs, $0.1 \mu \mathrm{l} \mathrm{Taq}$

WeiR (R) CCC TCA AAC ATC TAC
$2.0 \mu$ l buffer 10x, $1.6 \mu$ l dNTṔs, $0.2 \mu \mathrm{l}$ Taq

$4.0 \mu \mathrm{l}$ DNA, $0.4 \mu \mathrm{l}$ Enf1, $0.4 \mu \mathrm{l}$ Ent2, $4 \mu \mathrm{l} \mathrm{MgCl}, 2.0 \mu \mathrm{l}$ buffer 10x, $1.6 \mu \mathrm{l}$ dNTPs, $0.2 \mu \mathrm{l} \mathrm{Ta}$
4.0 $\mu \mathrm{l}$ DNA, $2 \mu \mathrm{l}$ Ef0027F, $2 \mu \mathrm{l}$ Ef0027R, $4 \mu \mathrm{l} \mathrm{MgCl}_{2}$.

35 cycles

regulator gene (518 bp)

${ }^{\mathrm{e}} 94^{\circ} \mathrm{C} /$

$30 \mathrm{~s}$

$16 \mathrm{~S}$ rRNA gene (300 and

$400 \mathrm{bp}$

$55^{\circ} \mathrm{C} / 30 \mathrm{~s}$

$72^{\circ} \mathrm{C} / 30 \mathrm{~s}$

eg4 ${ }^{\circ} \mathrm{Cl}$

${ }^{\mathrm{e}} 94{ }^{\circ} \mathrm{C}$

$30 \mathrm{~s}$
$67{ }^{\circ} \mathrm{C} / 30$

$72^{\circ} \mathrm{C}$

$1 \mathrm{~min}$

35 cycles

${ }^{\mathrm{e}} 94^{\circ} \mathrm{Cl}$

$30 \mathrm{~s}$

$67^{\circ} \mathrm{C} / 30 \mathrm{~s}$

$72{ }^{\circ} \mathrm{C} /$

$1 \mathrm{~min}$

35 cycles

Weissella spp. buffer 10x, $1.6 \mu \mathrm{l}$ dNTṔs, $0.1 \mu \mathrm{lTaq}$
16S rRNA gene

(872 bp)

16S rRNA gene

(872 bp)

16S rRNA gene (725 bp)

$30 \mathrm{~s}$

$55^{\circ} \mathrm{C} / 30 \mathrm{~s}$

$72^{\circ} \mathrm{C} / 30 \mathrm{~s}$

35 cycles
GCCACTATTTCTCGGACAG

Ec. faecalis ATCC 29212

Ke et al. (1999)

c. faecalis ATCC 29212

Dutka-Malen, Evers, and Courvalin (1995)

Dutka-Malen et al. (1995)

Ec. faecium LMG 8149

Mora, Fortina, Parini, and Manachini (1997)

\section{Ped. pentosaceus NCDO 813 $\quad$ Mora et al. (1997)}

a $10 \mathrm{mM}$ each primer (MWG Biotech AG, Fbersberg Germany); $5 \mathrm{mM} \mathrm{MgCl}_{2}, 2.5 \mathrm{mM}$ dNTṔs, Taq DNA polymerase (TaKaRa Ex TaqTM, TAKARA, BIO INC. Japan).

Initial denaturation at $95^{\circ} \mathrm{C}$ for $3 \mathrm{~min}$ and final extension of the amplified product at $72^{\circ} \mathrm{C}$ for $5 \mathrm{~min}$.

Initial denaturation at $95^{\circ} \mathrm{C}$ for $5 \mathrm{~min}$ and final extension of the amplified product at $72^{\circ} \mathrm{C}$ for $5 \mathrm{~min}$.

d Initial denaturation at $95^{\circ} \mathrm{C}$ for $5 \mathrm{~min}$ and final extension of the amplified product at $72{ }^{\circ} \mathrm{C}$ for $10 \mathrm{~min}$

e Initial denaturation at $95^{\circ} \mathrm{C}$ for $5 \mathrm{~min}$ and final extension of the amplified product at $72^{\circ} \mathrm{C}$ for $5 \mathrm{~min}$. 
Fournaud, \& Champommier, 1991). Although valuable from a practical point of view, results obtained by these methods are not always sufficient to characterize strains to species level, especially within the genera Lactobacillus (Ammor et al., 2005; Aquilanti, Zannini, Zocchetti, Osimani, \& Clementi, 2007) and Enterococcus (Velasco et al., 2004). SDS-PAGE of whole cell proteins (Samelis, Tsakalidou, Metaxopoulos, \& Kalantzpopulos, 1995), restriction fragment length polymorphism (RFLP) of 16S rRNA (Sanz, Selgas, Parejo, \& Ordrhez, 1998), hybridization with rRNA probes (Nissen \& Dainty, 1995), PCR with species-specific primers (Yost \& Nattress, 2000), temperature gradient gel electrophoresis (TGGE) of PCR products (Cocolin, Manzano, Cantoni, \& Comi, 2000), denaturing gradient gel electrophoresis (DGGE) (Cocolin, Manzano, Cantoni, \& Comi, 2001) and randomly amplified polymorphic DNA (RAPD)-PCR analysis (Berthier \& Ehrlich, 1999), have been reported to be more accurate.

In this paper, the phenotypic and genotypic diversity of LAB isolated from "Alheira" produced in seven different processing plants was studied.

\section{Material and methods}

\section{Identification of lacticacid bacteria}

\section{Origin and sampling of isolates}

"Alheiras", unwrapped, sealed in modified atmosphere packages or vacuum-packed, were collected from different retail stores. Samples collected from seven production plants in North-East Portugal were labelled Ef, Tp, Tx, Gr, Ag, Am and PV.

Twenty-five grams of each sample were added to $225 \mathrm{ml}$ of sterile buffered peptone water (Merck, Darmstadt, Germany), homogenized in a stomacher for $2 \mathrm{~min}$ and serial dilutions were plated onto De Man, Rogosa Sharpe (MRS) Agar (LabM, Bury, UK) and M17 agar (Merck). Plates were incubated under microaerophilic conditions for $72 \mathrm{~h}$ at $30^{\circ} \mathrm{C}$. Colonies were randomly selected, based on colony morphology, from plates having between 15 and 150 colonies and cultured in MRS or M17 broth for $48 \mathrm{~h}$ at $30^{\circ} \mathrm{C}$. Isolates were purified by repeated streaking onto the respective growth media. All isolates were tested for Gram reaction, oxidase and catalase production. Gram-positive, catalase-negative and oxidase-negative isolates were selected and stored at $-80^{\circ} \mathrm{C}$ in growth medium, supplemented with glycerol $(30 \%, \mathrm{v} / \mathrm{v}$, final concentration).

\section{Phenotypicand biochemical tests}

Isolates were sub-cultured twice in MRS or M17 broth at $30^{\circ} \mathrm{C}$ for $24 \mathrm{~h}$ before cell morphology was observed with an optical light microscope. All isolates were tested for $\mathrm{CO}_{2}$ production from glu- cose in MRS broth adjusted to $\mathrm{pH} 7.0$, fitted with Durham tubes (Müller, 1990). Incubation was for $48 \mathrm{~h}$ at $30^{\circ} \mathrm{C}$. Isolates were considered heterofermentative if gas had been formed. Growth at $10{ }^{\circ} \mathrm{C}$ and $45^{\circ} \mathrm{C}$ was tested by incubating the isolates in appropriated media ( $\mathrm{pH} 7.0$ ) for 7 and 2 days, respectively. Growth was recorded by an increase in turbidity.

Acid production from D-glucose, D-fructose, galactose, sucrose, lactose, maltose, mannitol, rhamnose, ribose, trehalose and D-xylose was determined using microtitre plates (Parente, Griego, \& Crudele, 2001). Filter-sterilized sugar ( $1 \mathrm{ml}$ of a $100 \mathrm{~g} / \mathrm{l}$ solution) was added to $9 \mathrm{ml}$ basal medium (MRS without glucose and meat extract and with $0.16 \mathrm{~g} / \mathrm{l}$ bromocresol purple, $\mathrm{pH}$ 7.0) and $180 \mu \mathrm{l}$ dispensed into each well. Cells harvested from 16-h-old broth cultures $\left(6000 \mathrm{~g}, 5 \mathrm{~min}, 20^{\circ} \mathrm{C}\right)$ were suspended in sterile saline and $20 \mu \mathrm{l}$ inoculated into each well. The microtitre plates were incubated under microaerophilic conditions at $30^{\circ} \mathrm{C}$ for $48 \mathrm{~h}$. A colour change from purple to yellow was regarded as a positive reaction. Hydrolysis of esculin was tested by adding $2 \mathrm{~g} / \mathrm{l}$ esculin (Sigma Diagnostics, St. Louis, MO, USA) and $5 \mathrm{~g} / \mathrm{l}$ ferric ammonium citrate (Sigma) to the basal medium. Incubation was as described before. A black colouration of the medium was regarded as a positive reaction. Growth in the presence of $4 \%$ and $6.5 \%(\mathrm{w} / \mathrm{v}) \mathrm{NaCl}$, and at $\mathrm{pH}$ 4.0 and $\mathrm{pH} 9.6$ was determined in MRS broth, adjusted with $1 \mathrm{~N}$ $\mathrm{HCl}$ or $\mathrm{NaOH}$ before autoclaving and supplemented with bromocresol purple. Microtitre plates were inoculated as described before. A colour change to yellow was recorded as growth. Arginine hydrolysis was tested by inoculating the isolates into MRS broth, supplemented with arginine ( $3 \mathrm{~g} / \mathrm{l})$ and ammonium citrate replaced by sodium citrate. Incubation was at $30^{\circ} \mathrm{C}$ for 4 days, as described before. Production of ammonia was detected by using Nessleŕs reagent (Carlo Erba, Rodano, MI, Italy). All tests were performed in triplicate.

\section{Genotypic tests}

DNA isolation : $\quad$ Two DNA extraction methods were used. Isolates collected from M17 agar were grown to mid-log phase in M17 broth (to an optical density of 1.4 at $600 \mathrm{~nm}$ ), harvested $(8000 \mathrm{~g}$, $\left.5 \mathrm{~min}, 4^{\circ} \mathrm{C}\right)$, rinsed twice with sterile saline $(0.9 \%, \mathrm{w} / \mathrm{v}, \mathrm{NaCl})$, suspended in $50 \mu \mathrm{l}$ sterile distilled water and boiled for $15 \mathrm{~min}$. The DNA of isolates collected from MRS plates was extracted with phenol-chloroform, as described by Dellaglio, Bottazzi, and Trovatelli (1973). Both sets of DNA extracts were frozen at $-20^{\circ} \mathrm{C}$.

PCR withs pecies-and genus-specific primers and $16 \mathrm{Sr}$ RNA gene sequencing. Isolates within each group were identified to genus and species level by using genus or species-specific primers. Representative strains were selected and the gene encoding $16 \mathrm{~S}$ rRNA sequenced. The DNA primers and PCR conditions used are

Table 2

Physiological and biochemical tests used to classify lactic acid bacteria isolated from "Alheira". The figures refer to the number of strains positive in each test.

\begin{tabular}{|c|c|c|c|c|c|c|c|c|c|c|c|}
\hline Morphology & $\begin{array}{l}\mathrm{CO}_{2} \\
\text { from } \\
\text { Glucose }\end{array}$ & $\begin{array}{l}\text { Growth } \\
\text { at } 10^{\circ} \mathrm{C}\end{array}$ & $\begin{array}{l}\text { Growth } \\
\text { at } 45^{\circ} \mathrm{C}\end{array}$ & $\begin{array}{l}\text { Growth in the } \\
\text { presence of } 4 \% \\
\mathrm{NaCl}\end{array}$ & $\begin{array}{l}\text { Growth in the } \\
\text { presence of } 6.5 \% \\
\mathrm{NaCl}\end{array}$ & $\begin{array}{l}\text { Growth } \\
\text { at pH } \\
4.4\end{array}$ & $\begin{array}{l}\text { Growth } \\
\text { at pH } \\
9.6\end{array}$ & $\begin{array}{l}\mathrm{NH}_{3} \text { from } \\
\text { Arginine }\end{array}$ & $\begin{array}{l}\text { Esculin } \\
\text { Hydrolysis }\end{array}$ & Preliminary classification $^{\mathrm{a}}$ & Group \\
\hline Rods & 0 & 90 & 85 & 87 & 69 & 90 & 0 & 3 & 90 & $\begin{array}{l}\text { Homofermentative or } \\
\text { facultatively Heterofermentative } \\
\text { lactobacilli }\end{array}$ & $\begin{array}{l}\text { G1 } \\
(\mathbf{9 0})^{\mathrm{b}}\end{array}$ \\
\hline Rods & 21 & 21 & 0 & 16 & 6 & 21 & 0 & 16 & 0 & $\begin{array}{l}\text { Obligately heterofermentative } \\
\text { lactobacilli or Weissella spp. }\end{array}$ & $\begin{array}{l}\text { G2 } \\
(21)\end{array}$ \\
\hline Cocci & 0 & 159 & 159 & 159 & 159 & 159 & 159 & 104 & 120 & Enterococcus spp. & $\begin{array}{l}\text { G3 } \\
(159)\end{array}$ \\
\hline Coccobacilli & 4 & 4 & 0 & 3 & 2 & 2 & 0 & 1 & 0 & Leuconostoc spp. & G4 (4) \\
\hline $\begin{array}{l}\text { Cocci in } \\
\text { tetrads }\end{array}$ & 0 & 9 & 6 & 9 & 4 & 9 & 3 & 6 & 9 & Pedioccocus spp. & G5 (9) \\
\hline
\end{tabular}

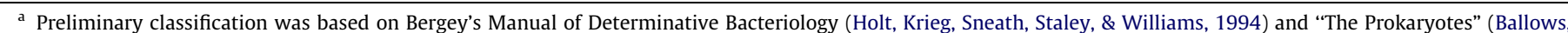
Trüper, Dworkin, Harder, \& Schleifer, 1992).

$\mathrm{b}$ Total number of strains isolated. 
Table 3

Sugar fermentation reactions recorded for lactic acid bacteria isolated from "Alheira". The numbers in superscript refer to the number of negative strains in each test.

\begin{tabular}{|c|c|c|c|c|c|c|c|c|c|c|c|c|c|c|c|c|c|}
\hline Group & $\begin{array}{l}\text { Biochemical } \\
\text { profile }\end{array}$ & $\begin{array}{l}\text { Esculin } \\
\text { hydrolysis }\end{array}$ & Fructose & Galactose & Glucose & Lactose & Maltose & Mannitol & Rhamnose & Ribose & Sorbitol & Sucrose & Trehalose & Xylose & $\begin{array}{l}\mathrm{NH}_{3} \\
\text { from } \\
\text { arginine }\end{array}$ & $\begin{array}{l}\text { Phenotypic } \\
\text { identification }^{\mathrm{a}}\end{array}$ & $\begin{array}{l}\text { Genotypic } \\
\text { identification }\end{array}$ \\
\hline \multirow[t]{5}{*}{ G1 } & (90) & G1.1. (76) & + & + & + & + & + & +1 & + & - & + & + & + & + & - & - & $\begin{array}{l}\text { L. plantarum; } L \\
\text { paraplantarum; } L . \\
\text { rhamnosus; } L . \\
\text { paracasei; } L . \text { pentosus }\end{array}$ \\
\hline & $\begin{array}{l}\text { L. plantarum } \\
\text { ( } 70) ; L \text {. } \\
\text { rhamnosus } \\
\text { (3); L. }\end{array}$ & & & & & & & & & & & & & & & $\begin{array}{l}\text { paraplantarum (1); } L . \\
\text { paracasei }(2)\end{array}$ & \\
\hline & G1.2. (4) & + & - & +1 & + & - & + & +1 & - & + & + & + & + & - & - & $\begin{array}{l}\text { L. plantarum; } L . \\
\text { paraplantarum; } L . \\
\text { rhamnosus; } L . \\
\text { paracasei; } L \text {. pentosus }\end{array}$ & $\begin{array}{l}\text { L. paraplantarum (2); } \\
\text { L. plantarum (1); L. } \\
\text { paracasei (1) }\end{array}$ \\
\hline & G1.3. (4) & + & + & - & + & + & + & + & - & + & + & + & + & - & - & $\begin{array}{l}\text { L. plantarum; } L . \\
\text { paraplantarum; } L . \\
\text { rhamnosus; } L . \\
\text { paracasei; } L . \text { pentosus }\end{array}$ & $\begin{array}{l}\text { L. rhamnosus (3); L. } \\
\text { paracasei (1) }\end{array}$ \\
\hline & G1.4. (3) & + & nd & + & + & + & - & + & - & + & - & + & + & - & - & L. plantarum & $\begin{array}{l}\text { L. zeae (2); L. } \\
\text { plantarum (1) }\end{array}$ \\
\hline $\begin{array}{r}\text { G1.5. } \\
(3)\end{array}$ & + & + & + & + & + & + & - & + & + & - & + & + & - & + & L. sakei & L. sakei (3) & \\
\hline \multirow[t]{2}{*}{ G2 } & $\begin{array}{l}\quad(\mathbf{2 1 )} \\
\text { L. brevis (7); } \\
\text { L. plantarum } \\
\text { (1) }\end{array}$ & G2.1. (8) & - & + & $t^{2}$ & + & + & +1 & - & - & + & - & + & + & + & + & L. brevis \\
\hline & G2.2. (11) & - & nd & + & + & + & + & - & nd & - & - & + & - & - & + & Weissella spp. & $\begin{array}{l}\text { Weissella spp. (6); W. } \\
\text { cibaria (3); } W . \\
\text { viridescens (1); } L . \\
\text { mesenteroides (1) }\end{array}$ \\
\hline $\begin{array}{r}\text { G2.3. } \\
(2)\end{array}$ & + & + & + & + & + & + & + & - & + & + & + & + & - & - & Not & determined & L. plantarum (2) \\
\hline \multirow[t]{3}{*}{ G3 } & (159) & $\begin{array}{l}\text { G3.1. } \\
(101)\end{array}$ & + & $t^{3}$ & + & + & $+1-$ & + & + & $+1-$ & + & + & $+^{2}$ & + & - & - & Enterococcus spp. \\
\hline & & & & & & & & & & & & & & & & $\begin{array}{l}\text { Enterococcus spp. } \\
\text { (32); E. faecalis (43); } \\
\text { E. faecium (26) }\end{array}$ & \\
\hline & G3.2. (44) & + & + & $t^{2}$ & + & + & + & + & $+1-$ & + & + & + & + & - & - & E. faecalis & E. faecalis (44) \\
\hline G3.3. & (14) & + & + & + & + & $+1-$ & + & + & - & + & - & + & + & - & + & E. faecium & $\begin{array}{l}\text { E. faecium (12); } P \text {. } \\
\text { pentosaceus (2) }\end{array}$ \\
\hline G4 (4) & G4. (4) & + & + & + & + & - & + & - & - & + & - & + & + & + & - & Ln. mesenteroides & $\begin{array}{l}\text { Ln. mesenteroides ( } 3 \text {; } \\
\text { P. pentosaceus (1) }\end{array}$ \\
\hline G5 (9) & G5. (9) & + & + & + & + & + & $t^{3}$ & & & + & - & - & + & + & + & Pediococcus spp. & $\begin{array}{l}\text { P. acidilactici (3); P. } \\
\text { pentosaceus (6) }\end{array}$ \\
\hline
\end{tabular}

nd, not determined.

Preliminary classification, based on Bergey's Manual of Determinative Bacteriology (Holt et al., 1994) and "The Prokaryotes" (Ballows et al., 1992).

b Using genus or species-specific primers, and 16S rRNA gene sequencing to confirm results. 
listed in Table 1. Samples without genomic DNA were used as negative controls. Amplified fragments were separated on agarose gels at a constant $100 \mathrm{~V}$. Tris-acetate (TAE) was used as buffer. Gels were stained with $0.5 \mu \mathrm{g} / \mathrm{ml}$ ethidium bromide (Sigma). A 100-bp DNA ladder (BioRad Laboratories, Richmond, CA) was used as molecular weight marker when the expected product size was less than 400 bp; otherwise Lambda DNA, digested with EcoR1 and HindIII (Roche, Indianapolis, USA) was used.

To confirm results, representative strains within each group were subjected to $16 \mathrm{~S}$ rRNA gene sequencing, as described by Felske, Rheims, Wolterink, Stackebrandt, and Akkermans (1997). The following primers were used: $8 \mathrm{~F}$ ( $5^{\prime}$-CAC GGA TCC AGA CTT TGA TYM TGG CTC AG-3') (Y=C+T; M = A + C) and $1512 \mathrm{R}\left(5^{\prime}-\right.$ GTG AAG CTT ACG GYT AGC TTG TTA CGA CTT-3'). PCR products were purified with the GFX PCR DNA and Band Purification kit (GE HealthCare, Amersham Biosciences, Amersham, UK) and used as templates. The ABI PRISMs BigDye ${ }^{\mathrm{TM}}$ Terminator Cycle Sequencing Ready Reaction Kit (PE Applied Biosystems, Foster City, CA) was used. Sequences obtained from an automatic DNA sequencer (ABI PRISMs 310 Genetic Analyser, PE Applied Biosystems) were aligned with sequences in Genbank using the BLAST program (Altschul et al., 1997).

Random amplified polymorphic DNA(RAPD) analyses : Strains identified as members of the genera Enterococcus and Lactobacillus were selected for further studies. The genetic heterogeneity of isolates that grouped within the most prevalent species was determined by numerical analysis of DNA profiles obtained by RAPDPCR.

DNA primers M13 (5'-GAG GGT GGC GGT TCT-3') and D8635 (5'-GAG CGG CCA AAG GGA GCA GAC-3') of Huey and Hall (1989) were used. RAPD-PCR was performed on total (genomic and plasmid) DNA, as described by Andrighetto, Zampese, and Lombardi (2001). The $25 \mu$ reaction volume contained $0.99 \mathrm{mM}$ primer M13, $1 \times$ PCR buffer (MBI Fermentas, Mundolsheim, France), $2.5 \mathrm{mM} \mathrm{MgCl}_{2}$ (MBI Fermentas), $0.15 \mathrm{mM}$ dNTP (Abgene, Surrey, UK) and $1 \mathrm{U}$ Taq DNA polymerase (MBI Fermentas). The second amplification contained $0.88 \mathrm{mM}$ primer D8635, $1 \times$ PCR Buffer, $2.5 \mathrm{mM} \mathrm{MgCl}_{2}, 0.2 \mathrm{mM}$ dNTP and $1 \mathrm{U}$ Taq DNA polymerase. Amplification was in a DNA thermal cycler (My Cycler ${ }^{\mathrm{TM}}$ Thermal Cycler Firmware, BioRad Laboratories) by using the following program: Initial denaturation at $94^{\circ} \mathrm{C}$ for 2 min, 35 cycles of 1 min per cycle at $94^{\circ} \mathrm{C}$, and $1 \mathrm{~min}$ at $46.9^{\circ} \mathrm{C}$, followed by an increase to $72{ }^{\circ} \mathrm{C}$ over $90 \mathrm{~s}$. Extension of the amplified product was at $72{ }^{\circ} \mathrm{C}$ for $10 \mathrm{~min}$. Amplified products were separated by electrophoresis in $1.2 \%(\mathrm{w} / \mathrm{v})$ agarose gels in $1 \times$ TAE buffer at $80 \mathrm{~V}$ for $2 \mathrm{~h}$. Gels were stained in TAE buffer containing $0.5 \mu \mathrm{g} / \mathrm{ml}$ ethidium bromide. A 100-bp DNA ladder (BioRad Laboratories) was used as molecular weight marker.

Banding patterns were analysed using Gel Compare, Version 4.1 (Applied Maths, Kortrijk, Belgium). Similarities were calculated by using the Dice product-moment correlation coefficient. Dendrograms were obtained by means of the Unweighted Pair Group Method using Arithmetic Average (UPGMA) clustering algorithm (Vauterin \& Vauterin, 1992).

\section{Results and discussion}

Based on a few key biochemical characteristics, 283 isolates were separated into five phenotypic groups (Table 2). All isolates in groups G1 and G2 were rod-shaped. Because none of the isolates in group $\mathrm{G} 1$ produced $\mathrm{CO}_{2}$ from the fermentation of glucose, they were tentatively classified as homofermentative (group I Lactobacillus) and facultatively heterofermentative (group II Lactobacillus). Most of the isolates ( 85 out of 90 ) grew at $45^{\circ} \mathrm{C}$, suggesting that

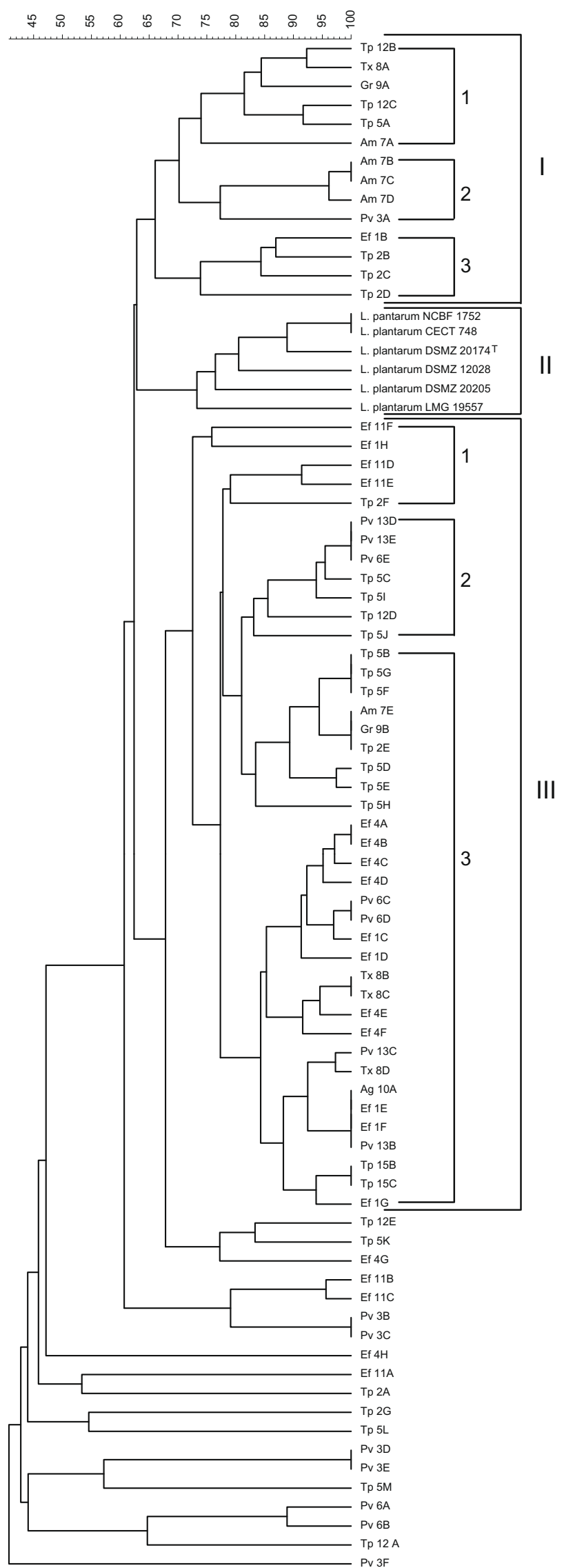

Fig. 1. Numerical analysis of RAPD-PCR profiles obtained for strains of $L$. plantarum isolated from "Alheira" manufactured in seven different plants. Clusters are indicated with Roman numerals. Ef, Tp, Am, Gr, Tx, Ag and PV are the producers. 
they belong to the group I - Lactobacillus. Five isolates did not grow at $45^{\circ} \mathrm{C}$ and were tentatively classified as members of the group II - Lactobacillus. Isolates from group G2 produced $\mathrm{CO}_{2}$ from the fermentation of glucose and were classified as members of group III Lactobacillus or Weissella. Isolates collected from M17 medium were coccoid, grew at $\mathrm{pH} 9.6$ and in the presence of $6.5 \% \mathrm{NaCl}$ (Table 2), and were tentatively classified as Enterococcus spp. (group G3, Table 2). Four isolates had a coccobacillus (oval) shape and were tentatively classified as members of the genus Leuconostoc (group G4, Table 2). Nine isolates were cocci arranged in tetrads and were tentatively classified as Pediococcus spp. (group G5, Table 2).

Sugar fermentation reactions separated the 90 isolates in group G1 into five subgroups (G1.1-G1.5, Table 3). Most of these isolates (84) shared the same sugar fermentation reactions and were classified as L. plantarum, Lactobacillus paraplantarum, Lactobacillus rhamnosus, Lactobacillus paracasei and Lactobacillus pentosus (Table 3). Small differences in sugar fermentation reactions separated the strains into subgroups G1.1, G1.2 (fructose and lactose not fermented), and G1.3 (fructose fermented, but galactose not fermented). Three isolates did not ferment maltose and sorbitol and were tentatively classified as strains of $L$. plantarum (subgroup G1.4, Table 3). Another three isolates did not ferment mannitol and sorbitol, but fermented rhamnose and produced $\mathrm{NH}_{3}$ from arginine, and were tentatively classified as strains of L. sakei (subgroup G1.5, Table 3). Isolates in group G2 were rod-shaped and were separated into three subgroups (G2.1-G2.3, Table 3). Eight of the isolates were tentatively classified as strains of Lactobacillus brevis (subgroup G2.1) and 11 as strains belonging to the genus Weissella (subgroup G2.2). Two isolates remained unclassified (subgroup G2.3). The vast majority of isolates (159) were coccoid and resembled a homogeneous collection of strains, tentatively classified as members of the genus Enterococcus (group G3, Table 3 ). Most of the isolates (101) could not be identified to species level and were tentatively classified as Enterococcus spp. (subgroup G3.1). The remaining isolates were classified as Enterococcus faecalis (44 strains in subgroup G3.2) and Enterococcus faecium (14 strains in subgroup G3.3). Four Isolates with an oval (coccobacillus) morphology were placed in group G4 and were tentatively classified as Leuconostoc mesenteroides (Table 3). Nine isolates with a coccoid morphology and arranged in tetrads were placed in group G5 and were tentatively classified as Pediococcus spp.

All the isolates were identified to species level by PCR with species- and genus-specific primers. Representative strains from each group were subjected to 16S rRNA sequencing. The majority of strains in group G1 (72 out of 90) were identified as L. plantarum, six as L. rhamnosus, three as $L$. paraplantarum, four as $L$. paracasei, two as Lactobacillus zeae and three as L. sakei (Table 3). Strains in Group G2 were genotypically heterogeneous and represented $L$. plantarum (three strains), L. brevis (seven strains), Weissella sp. (six strains), Weissella cibaria (three strains), Weissella viridescens (one strain) and $L$. mesenteroides (one strain). The majority of strains (87 out of 159) in group G3 were identified as E. faecalis and grouped into subgroup G3.2 as a homogeneous collection of strains. Thirty-eight strains were identified as E. faecium and two as Pediococcus pentosaceus (Table 3). Thirty-two strains remained unidentified and were regarded as Enterococcus spp. (Table 3). Three isolates in group G4 were identified as L. mesenteroides and one as $P$. pentosaceus (Table 3 ). Isolates in group G5 belonged to Pediococcus acidilactici and $P$. pentosaceus (Table 3 ).

The genotypic relatedness of $L$. plantarum strains isolated from "Alheira", determined by RAPD-PCR, is shown in Fig. 1. Fourteen strains shared similar DNA banding profiles and grouped in Cluster I at 66\%. Three subgroups were identified in Cluster I at $\geqslant 70 \%$. Forty-two strains were genotypically closely related and grouped in Cluster III at 72\%. Three subgroups were identified within Clus-

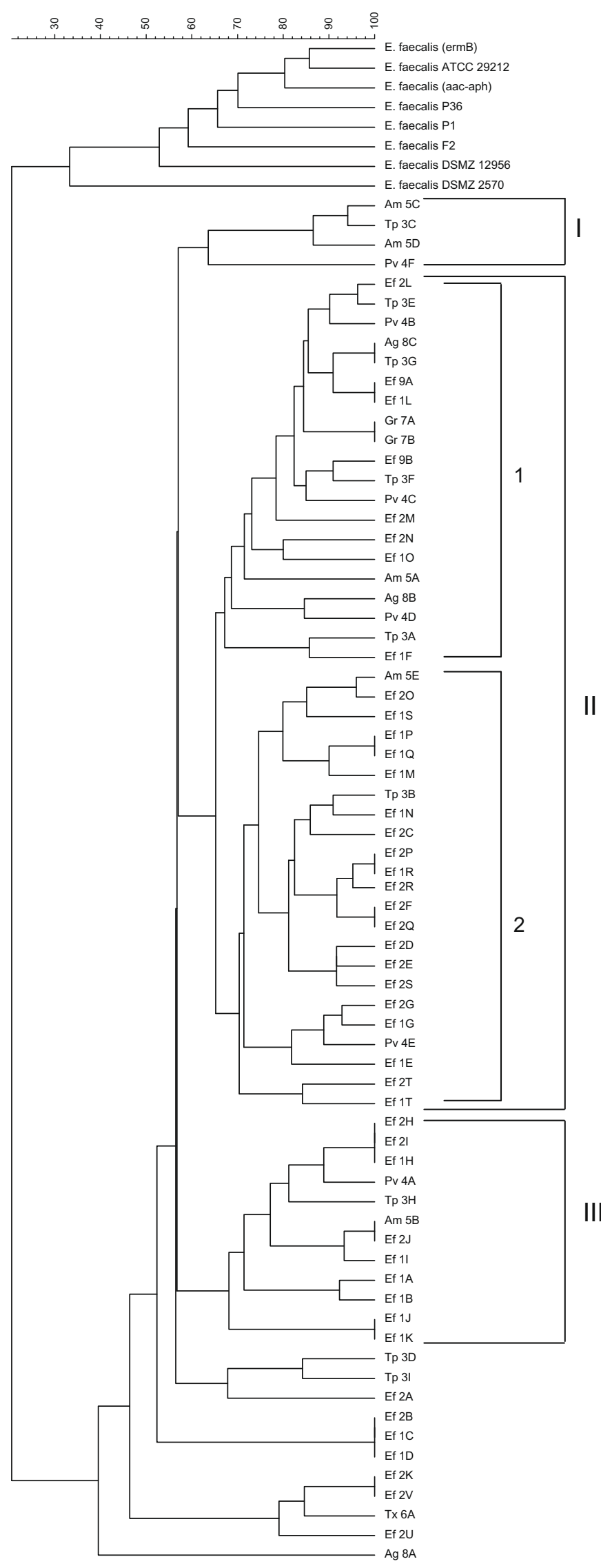

Fig. 2. Numerical analysis of RAPD-PCR profiles obtained from strains of $E$. faecalis isolated from "Alheira" manufactured in seven different plants. Clusters are indicated with Roman numerals. Ef, Tp, Am, Gr, Tx, Ag and PV are the producers. 
Table 4

Identification of strains isolated from seven producers of "Alheiras".

\begin{tabular}{|c|c|c|c|c|c|c|c|c|}
\hline Species & Ef & Tp & PV & Am & $\mathrm{Tx}$ & $\mathrm{Gr}$ & $\mathrm{Ag}$ & Total \\
\hline L. plantarum & 21 & 27 & 15 & 5 & 4 & 2 & 1 & 75 \\
\hline L. paraplantarum & - & 2 & - & - & 1 & - & - & 3 \\
\hline L. rhamnosus & 4 & - & - & 1 & 1 & - & - & 6 \\
\hline L. sakei & - & 1 & - & - & - & 2 & - & 3 \\
\hline L. zeae & 2 & - & - & - & - & - & - & 2 \\
\hline L. paracasei & 4 & - & - & - & - & - & - & 4 \\
\hline L. mesenteroides & 1 & 2 & - & - & 1 & - & - & 4 \\
\hline L. brevis & 1 & 1 & 2 & - & 1 & - & 2 & 7 \\
\hline Enterococcus spp. & $1+12^{\mathrm{a}}$ & $1+3^{a}$ & $5^{\mathrm{a}}$ & $1^{\mathrm{a}}$ & $1+1^{a}$ & $1^{\mathrm{a}}$ & $5+1^{a}$ & $8+24^{a}$ \\
\hline E. faecalis & $6+44^{a}$ & $8+9^{a}$ & $6^{\mathrm{a}}$ & $5^{a}$ & $1^{\mathrm{a}}$ & $2^{a}$ & $3+3^{a}$ & $17+70^{\mathrm{a}}$ \\
\hline E. faecium & $17^{\mathrm{a}}$ & $1+9^{a}$ & $1+5^{a}$ & - & $3^{a}$ & $2^{\mathrm{a}}$ & - & $2+36^{\mathrm{a}}$ \\
\hline P. acidilactici & 1 & - & 1 & - & - & - & 1 & 3 \\
\hline P. pentosaceus & 3 & 3 & - & - & 1 & - & 2 & 9 \\
\hline Weissella spp. & 2 & 1 & 3 & - & - & - & - & 6 \\
\hline W. cibaria & 3 & - & - & - & - & - & - & 3 \\
\hline W. viridescens & - & - & 1 & - & - & - & - & 1 \\
\hline Total & $49+73^{a}$ & $47+21^{a}$ & $23+16^{\mathrm{a}}$ & $6+6^{a}$ & $10+5^{a}$ & $4+5^{a}$ & $14+4^{a}$ & $153+130^{\mathrm{a}}=283$ \\
\hline
\end{tabular}

a Isolated on M17 agar. All other organisms were isolated on MRS agar.

ter III, each with a specific level of relatedness. Six reference strains of $L$. plantarum grouped in Cluster II at $73 \%$ and were genotypically closer related to strains in Cluster I than strains in Cluster III. This suggests that at least 14 strains (grouped in Cluster I) originated from the type strain of $L$. plantarum (DSMZ $20174^{\mathrm{T}}$ ) or closely related strains. It also suggests that 42 strains (grouped in Cluster III) had evolved to become less related to the type strain of $L$. plantarum. Nineteen strains were identified as $L$. plantarum, but were genotypically not closely related to the strains in Clusters I, II and III and formed smaller groups with little intra- and inter-genotypic similarity. Based on these results, $L$. plantarum consists of a heterogeneous collection of strains, similar to findings reported by Duffner and óConnel (1995) and Molenaar et al. (2005). More strains of $L$. plantarum will have to be studied to determine the taxonomic status of the species. It is also evident that strains from Cluster III form the core group within the L. plantarum strains isolated from "Alheira". Strains within each of the two clusters (I and III) were from different "Alheira" producers, suggesting that specific ingredients, method of production and area did not select for a specific group of strains with specific genetic characteristics.

The genotypic relatedness of 70 of the original 87 strains of $E$. faecalis is shown in Fig. 2. Three well-separated clusters were identified. Cluster I contained four strains grouped at 64\%. Cluster II consisted of 43 strains grouped at $66 \%$, separated into two subgroups. Cluster III consisted of 12 strains, grouped at $68 \%$. The eight reference strains of $E$. faecalis and 11 strains isolated from "Alheira" did not group into any of the three clusters. This suggested that the E. faecalis strains isolated from "Alheira" are genotypically not closely related to the type strain and other reference strains included in this study. Clusters I and II contained strains isolated from all producers. Cluster III contained 12 strains, mostly isolated from producer Ef. The genetic diversity could be explained by selective pressure inflicted on the strains in "Alheira". As far as we could determine, this is the first detailed taxonomic study on E. faecalis in "Alheira". Further research is needed to determine if the strains are characteristic for "Alheira" from a specific producer. It may also be that the strains represent new species within the genus Enterococcus.

The study has shown that "Alheira" contains a large number of LAB. Since these bacteria play an important role in meat fermentation, it is safe to assume they will influence the aroma and taste of the final product. LAB are also known to produce antimicrobial compounds, including bacteriocins, and may be used to extend the shelf life of the product. Identification of the strains is the first step towards the selection of starter cultures. By choosing the correct strains, "Alheira”, with unique organoleptic properties, may be developed.

Physiological and biochemical tests proved valuable in the preliminary identification of the lactic acid bacteria (Teixeira et al., 1997). However, in the present study, the identity of some isolates could only be confirmed by PCR with species- and genus-specific primers. To determine the specificity of this technique, representative strains within each group were subjected to 16S rRNA gene sequencing, confirming the results obtained by PCR. RAPD-PCR has indicated that $L$. plantarum and E. faecalis isolated from different producers are genetically diverse, suggesting that conditions in "Alheira" from a specific producer do not select for a homogeneous collection of strains. Similar findings have been reported for studies conducted on sausages produced in Greece, Hungary and Italy (Rantsiou, Drosinos, Gialitaki, Urso et al., 2005; Rantsiou, Drosinos, Gialitaki, Metaxopoulos et al., 2006; Urso, Comi, \& Cocolin, 2006).

The distribution of isolates between different samples and thus amongst different producers, is indicated in Table 4. It is interesting to note that L. plantarum was isolated from all samples of "Alheira" (in total 75 isolates, which represented $27 \%$ of all isolates). Similar results have been reported for Greek fermented sausage (Drosinos et al., 2005), Botillo (Fontán, Lorenzo, Martínez, Franco, \& Carballo, 2007), Sardinian and regional Friuli-VeneziaGiulia sausage (Aquilanti et al., 2007; Urso et al., 2006). L. brevis was found in five different "Alheiras", but at low numbers. A few other isolates were classified as $L$. paraplantarum, $L$. rhamnosus, $L$. sakei, $L$. mesenteroides, $P$. pentosaceus, P. acidilactici, $W$. cibaria, $W$. viridescens and E. faecium. L. zeae and L. paracasei were present in sample Ef. The presence of $L A B$ and such a large variation of strains are not surprising, as different production methods, recipes and raw materials were used (bread, spices). Furthermore, the fermentation process is not controlled, with a low ripening time and a high $\mathrm{a}_{\mathrm{w}}$ of the final product. Others factors that may contribute to the variability in strains is the manner in which the final product is stored and distributed.

Enterococcus spp. were isolated from all samples, with $E$. faecalis being the dominant species (87 isolates in total; 20\% from MRS medium and $80 \%$ from M17 medium). E. faecium was the second most dominant (38 strains). Enterococci are frequently isolated from fermented sausages, especially in products with a high $\mathrm{pH}$ and in the absence of competitive starter cultures (Hugas, Garriga, \& Aymerich, 2003). Apart from the glycolytic, proteolytic and lipolytic activities of enterococci, the role of these organisms in fer- 
mented sausages has not been studied in detail (Sarantinopoulos et al., 2001). The ability of enterococci to promote health and illness at the same time is not well understood. They produce antimicrobial compounds, including bacteriocins, that may extend the shelf life of fresh products and they may contribute to the sensorial quality of fermented foods. However, a number of enterococci have been associated with the formation of biogenic amines and contain virulence genes and have been associated with nosocomial and opportunistic infections (Franz, Stiles, Schleifer, \& Holzapfel, 2001).

A vast number of LAB were isolated from "Alheira", despite the high temperatures the ingredients were exposed to. It is important to note that "Alheira" is smoked at low temperatures and had high $a_{w}$. Unlike other fermented meat products, "Alheira" is exposed to a short ripening period. Many strains of LAB will withstand these conditions. It is thus not surprising to isolate specific groups of LAB from "Alheira". Although L. plantarum and E. faecalis were the dominant lactic acid bacteria in "Alheira", strains within these species are phenotypically and genetically different and may even represent new species. The strains classified as E. faecalis will have to be tested for virulence. This study forms the basis from which safe starter cultures could be selected for production of "Alheira".

\section{Acknowledgements}

This work received financial support via project POCTI/AGG/ 39587/2001, Fundação para a Ciência e Tecnologia (FCT)/Fundo Europeu Desenvolvimento Regional (FEDER), Portugal and National Research Foundation (NRF), South Africa. Financial support for author $\mathrm{H}$. Albano was provided by $\mathrm{PhD}$ fellowship, SFRH/BD/ $13161 / 2003$ (FCT).

\section{References}

Altschul, S. F., Madden, T. L., Shaffer, A. A., Zhang, J., Zhang, Z., Miller, W., et al. (1997). Gapped BLAST and PSI-BLAST: A new generation of protein database search programs. Nucleic Acids Research, 25, 3389-3402.

Ammor, S., Rachman, C., Chaillou, S., Prévost, H., Dousset, X., Zagorec, M., et al. (2005). Phenotypic and genotypic identification of lactic acid bacteria isolated from a small-scale facility producing traditional dry sausages. Food Microbiology, 22, 373-382.

Andrighetto, C., Zampese, L., \& Lombardi, A. (2001). RAPD-PCR characterization of lactobacilli isolated from artisanal meat plants and traditional fermented sausages of Veneto region (Italy). Letters in Applied Microbiology, 33, 26-30.

Aquilanti, L., Zannini, E., Zocchetti, A., Osimani, A., \& Clementi, F. (2007). Polyphasic characterization of indigenous lactobacilli and lactococci from PDO Canestrato Pugliese cheese. LWT - Food Science and Technology, 40, 1146-1155.

Bacus, J. N. (1986). Fermented meat and poultry products. In A. M. Pearson \& T. R. Dutson (Eds.), Advances in meat research, meat and poultry microbiology (pp. 123-164). London: Macmillan.

Ballows, A., Trüper, H. G., Dworkin, M., Harder, W., \& Schleifer, K. -H. (1992). The prokaryotes, a handbook on the biology of bacteria: Ecophysiology, isolation identification, applications (2nd ed., Vol. II). Springer-Verlag.

Berthier, F., \& Ehrlich, S. D. (1998). Rapid species identification within two groups of closely related lactobacilli using PCR primers that target the 16S/23S rRNA spacer region. FEMS Microbiology Letters, 161, 97-106.

Berthier, F., \& Ehrlich, S. D. (1999). Genetic diversity within Lactobacillus sakei and Lactobacillus curvatus and design of PCR primers for its detection using randomly amplified polymorphic DNA. International Journal of Systematic Bacteriology, 49, 997-1007.

Cocolin, L., Manzano, M., Cantoni, C., \& Comi, G. (2000). Development of a rapid method for the identification of Lactobacillus spp. isolated from naturally fermented Italian sausages using a polymerase chain reaction-temperature gradient gel electrophoresis. Letters in Applied Microbiology, 30, 126-129.

Cocolin, L., Manzano, M., Cantoni, C., \& Comi, G. (2001). Denaturing gradient ge electrophoresis analysis of the 16S rRNA gene V1 region to monitor dynamic changes in the bacterial population during fermentation of Italian sausages. Applied and Environmental Microbiology, 67, 5113-5121.

Dellaglio, F., Bottazzi, V., \& Trovatelli, L. D. (1973). Deoxyribonucleic acid homology and base composition in some thermophylic lactobacilli. Journal of General Microbiology, 74, 289-297.

Dellapina, G., Blanco, D., Pancini, E., Barbuti, S., \& Campanini, M. (1994) Microbiological evolution in Italian Felino, Milan and Hungarian-style salami. Industria Conserve, 69, 85-90.

Drosinos, E. H., Mataragas, M., Xiraphi, N., Moschonas, G., Gaitis, F., \& Metaxopoulos J. (2005). Characterization of the microbial flora from a traditional Greek fermented sausage. Meat Science, 69, 307-317.
Duffner, F., \& OConnel, M. (1995). Comparative evaluation of plasmid profiling and rybotyping in the analysis of Lactobacillus plantarum strains heterogeneity in silage. Journal of Applied Bacteriology, 78, 20-27.

Dutka-Malen, S., Evers, S., \& Courvalin, P. (1995). Detection of glycopeptide resistance genotypes and identification to the species level of clinically relevant enterococci by PCR. Journal of Clinical Microbiology, 33, 24-27.

Felske, A., Rheims, W., Wolterink, A., Stackebrandt, E., \& Akkermans, A. D. L. (1997). Ribosome analysis reveals prominent activity of an uncultured member of the class Actinobacteria in grassland soils. Microbiology, 143, 2983-2989.

Ferreira, V., Barbosa, J., Silva, J., Felício, M. T., Mena, C., Hogg, T., et al. (2007). Characterisation of alheiras, traditional sausages produced in the North of Portugal, with respect to their microbiological safety. Food Control, 18, 436-440.

Ferreira, V., Barbosa, J., Vendeiro, S., Mota, A., Silva, F., Monteiro, M. J., et al. (2006). Chemical and microbiological characterization of alheira: A typical Portuguese fermented sausage with particular reference to factors relating to food safety. Meat Science, 73, 570-575.

Fontán, M. C. G., Lorenzo, J. M., Martínez, S., Franco, I., \& Carballo, J. (2007). Microbiological characteristics of Botillo, a Spanish traditional pork sausage. LWT - Food Science and Technology, 40, 1610-1622.

Franz, C. M. A. P., Stiles, M. E., Schleifer, K. H., \& Holzapfel, W. H. (2001). Enterococci in foods - a conundrum for food safety. International Journal of Food Microbiology, 88, 105-122.

Guarneri, T., Rossetti, L., \& Giraffa, G. (2001). Rapid identification of Lactobacillus brevis using the polymerase chain reaction. Letters in Applied Microbiology, 33, 377-381.

Holt, J. G., Krieg, N. R., Sneath, P. H. A., Staley, J. T., \& Williams, S. T. (1994). Bergey's manual of determinative bacteriology (9th ed.). PA, USA: Lippincolt Williams and Wilkins.

Huey, B., \& Hall, J. (1989). Hypervariable DNA fingerprinting in Escherichia coli: Minisatellite probe from bacteriophage M13. Journal of Bacteriology, 171 2528-2532.

Hugas, M., Garriga, M., \& Aymerich, M. T. (2003). Functionality of enterococci in meat products. International Journal of Food Microbiology, 88, 223-233.

Jang, J., Kim, B., Lee, J., Kim, J., Jeong, G., \& Han, H. (2002). Identification of Weissella species by the genus-specific amplified ribosomal DNA restriction analysis. FEMS Microbiology Letters, 212, 29-34.

Ke, D., Picard, F. J., Martineau, F., Ménard, C., Roy, P. H., Ouellette, M., et al. (1999). Development of a PCR assay for rapid detection of enterococci. Journal of Clinical Microbiology, 37, 3497-3503.

Lee, H., Park, S., \& Kim, J. (2000). Multiplex PCR-based detection and identification of Leuconostoc species. FEMS Microbiology Letters, 193, 243-247.

Molenaar, D., Bringel, F., Schuren, F. H., De Vos, W. M., Siezen, R. J., \& Kleerebezem, M. (2005). Exploring Lactobacillus plantarum genome diversity by using microarrays. Journal of Bacteriology, 187, 6119-6127.

Montel, M. C., Talon, R., Fournaud, J., \& Champommier, M. C. (1991). A simplified Key for identifying homofermentative Lactobacillus and Carnobacterium spp. from meat. Journal of Applied Bacteriology, 70, 469-472.

Mora, D., Fortina, M. G., Parini, C., \& Manachini, P. L. (1997). Identification of Pediococcus acidilactici and Pediococcus pentosaceus based on 16S rRNA and ldhD gene-targeted multiplex PCR analysis. FEMS Microbiology Letters, 151, 231-236.

Moretti, V. M., Madonia, G., Diaferia, C. Mentasti, T., Paleari, M. A., Panseri, S, et al. (2004). Chemical and microbiological parameters and sensory attributes of a typical Sicilian salami ripened in different conditions. Meat Science, 66, $845-854$

Müller, T. (1990). Comparison of methods for differentiation between homofermentative and heterofermentative lactic acid bacteria. Zentralblatt Mikrobiologie, 145, 363-366.

Nissen, H., \& Dainty, R. (1995). Comparison of the use of rRNA probes and conventional methods in identifying strains of Lactobacillus sake and L. curvatus isolated from meat. International Journal of Food Microbiology, 30, 126-129.

Papamanoli, E., Kotzekidou, P., Tzanetakis, N., \& Litopoulou-Tzanetaki, E. (2003) Characterization of lactic acid bacteria isolated from a Greek dry-fermented sausage in respect to their technological and probiotic properties. Meat Science, $65,859-867$.

Parente, E., Griego, S., \& Crudele, M. A. (2001). Phenotypic diversity of lactic acid bacteria isolated from fermented sausages produced in Basilicata (southern Italy). Journal of Applied Microbiology, 90, 943-952.

Rantsiou, K., Drosinos, E., Gialitaki, M., Metaxopoulos, I., Comi, G., \& Cocolin, L (2006). Use of molecular tools to characterize Lactobacillus spp. isolated from Greek traditional fermented sausages. International Journal of Food Microbiology, $112,215-222$

Rantsiou, K., Drosinos, E., Gialitaki, M., Urso, R., Krommer, J., Gasparik-Reichardt, J., et al. (2005). Molecular characterization of Lactobacillus species isolated from natural fermented sausages produced in Greece, Hungary and Italy. Food Microbiology, 22, 19-28.

Roy, D., Sirois, S., \& Vincent, D. (2001). Molecular discrimination of lactobacilli used as starter and probiotic cultures by amplified ribosomal DNA restriction analysis. Currents Microbiology, 42, 282-289.

Samelis, J., Tsakalidou, E., Metaxopoulos, J., \& Kalantzpopulos, G. (1995). Differentiation of Lactobacillus sake and L. curvatus isolated from naturally fermented Greek dry salami by SDS-PAGE of whole-cell proteins. Journal of Applied Bacteriology, 78, 157-163.

Sanz, B., Selgas, D., Parejo, I., \& Ordrhez, J. A. (1998). Characteristics of lactobacilli isolated from dry fermented sausages. International Journal of Food Microbiology, $6,199-205$ 
Sarantinopoulos, P., Andrighetto, C., Georgalaki, M. D., Rea, M. C., Lombardi, A., Cogan, T. M., et al. (2001). Biochemical properties of enterococci relevant to their technological performance. International Dairy Journal, 11, 621-647.

Talon, R., Leroy, S., \& Lebert, I. (2007). Microbial ecosystems of traditional fermented meat products: The importance of indigenous starters. Meat Science, 77, 55-62.

Teixeira, L. M., Carvalho, M. G., Merquior, V. L., Steigerwalt, A. G., Brenner, D. J., \& Facklam, R. R. (1997). Phenotypic and genotypic characterization of Vagococcus fluvialis, including strains isolated from human sources. Journal of Clinical Microbiology, 35, 2778-2781.

Torriani, S., Felis, G. E., \& Dellaglio, F. (2001). Differentiation of Lactobacillus plantarum, $L$. Pentosus, and $L$. paraplantarum by recA gene sequence analysis and multiplex PCR assay with recA gene-derived primers. Applied and Environmental Microbiology, 67, 3450-3454.

Urso, R., Comi, G., \& Cocolin, L. (2006). Ecology of lactic acid bacteria in Italian fermented sausages: Isolation, identification and molecular characterization. Systematic and Applied Microbiology, 29, 671-680.
Vauterin, L., \& Vauterin, P. (1992). Computer-aided objective comparison of electrophoretic patterns for grouping and identification of microorganisms. European Microbiology, 1, 37-41.

Velasco, D., Perez, S., Peña, F., Angeles Dominguez, M., Cartelle, M., Molina, F., et al 2004). Lack of correlation between phenotypic techniques and PCR-based genotypic methods for identification of Enterococcus spp.. Diagnostic Microbiology and Infectious Disease, 49, 151-156.

Ward, L. J. H., \& Timmins, M. J. (1999). Differentiation of Lactobacillus casei, Lactobacillus paracasei and Lactobacillus rhamnosus by polymerase chain reaction. Letters in Applied Microbiology, 29, 90-92.

Yost, C. K., \& Nattress, F. M. (2000). The use of multiplex PCR reactions to characterize populations of lactic acid bacteria associated with meat spoilage. Letters in Applied Microbiology, 31, 129-133. 